\title{
Global Retrofitting Strategies for an Existing Three-storied RC School Building in Mandalay, Myanmar
}

\author{
Thiri Thwe ${ }^{1, *}$, Nang Su Le' Mya Thwin ${ }^{1}$, and Ne Min Hein ${ }^{2}$ \\ ${ }^{1}$ Department of Civil Engineering, Mandalay Technological University, Mandalay 05072, Myanmar \\ ${ }^{2}$ Brilliant Construction Project Management Co., Ltd., Yangon 11071, Myanmar \\ *Corresponding author: thirithwe9900@gmail.com
}

\author{
KEYWORDS \\ Non-seismic \\ Priority Index \\ Pushover analysis \\ Retrofit strategies \\ Steel plate shear wall \\ SUBMITTED 8 May 2020 \\ REVISED 6 July 2020 \\ ACCEPTED 29 July 2020
}

\begin{abstract}
Low to severe earthquakes occur around the world every year, damaging and causing structural failure in buildings. Consequently, seismic improvements are required for existing buildings that are vulnerable to damage by seismic forces. The objective of this study was to investigate retrofitting strategies in terms of their sustainability. Mandalay, Myanmar, was selected as the study area as it is located near the Sagaing fault, which itself is in a strong earthquake zone (seismic zone 4). A threestoried RC building with a non-seismic design was selected as a case study building. An investigation was carried out into the performance and vulnerability of the building under three earthquake hazard levels. The vulnerability index value was calculated using the Priority Index method. Meanwhile, nonlinear static pushover analysis was performed to investigate the performance of the existing building using SAP2000 V14 software. Four different types of retrofitting strategies were considered, namely reinforced concrete shear walls with openings, reinforced concrete shear walls without openings, steel plate shear walls, and finally steel bracing. Among these, it was found that the use of steel plate shear walls was the best retrofitting technique, owing to it having the best performance along with the lowest displacement. Its performance level reached up to the Immediate Occupancy (IO) level even under the conditions of a Maximum Consider Earthquake (MCE).
\end{abstract}

(c) The Author(s) 2020. This article is distributed under a Creative Commons Attribution-ShareAlike 4.0 International license.

\section{INTRODUCTION}

Earthquakes are one of the serious natural disasters on Earth. Unlike other disasters, there is no sign or warning to enable preparations against damage or the collapse of buildings caused by an earthquake. The only way to prevent this damage is to consider the seismic load in new and existing buildings. Non-seismically designed buildings have deficient lateral load resistance and can rapidly lose their performance during an earthquake, leading to collapse. Therefore, both gravity loads and lateral loads should be considered in the analysis of new and existing buildings.

According to the surveying data from the Mandalay City Development Committee, most of the existing buildings in Mandalay, Myanmar, have been designed only for gravity loads, not for the seismic load. Mandalay is situated in seismic zone 4 near the Sagaing fault (Thant et al. 2012), and hence the main consideration must be seismic load. The proposed school building was mostly focused on the effects of gravity loads and they did not contribute to providing seismic loads as stated in as-built drawings. While seismic load was considered by adding to the original design, the performance of the building was poor and thus, retrofitting strategies had to be examined.

In this study, there were two main parts. The vulnerability and performance level of the existing building was the first part of the study. The second part was to improve the performance level of the existing school building by retrofitting. The existing building was retrofitted by considering externally strengthening the structure, with the insertion of bracing or shear walls at some locations. The purpose of the study was to upgrade the seismic safety of the existing building to the desired level with the best and most appropriate techniques in a short time, with minimum cost (Thwe and Thwin 2020).

\section{MATERIALS AND METHODS}

\subsection{Study area}

The proposed building was No-14 Basic Education High School, a three-storied, non-seismic reinforced concrete (RC) building, located on 80th street between 32nd and 33rd street, Chan Aye Thar Zan Township, Mandalay, Myanmar. Mandalay is very close to the Sagaing fault, which is a major fault in Myanmar. Therefore, the proposed school building was selected to investigate the existing structural performance level and to identify which type of retrofitting techniques would be suitable for it.

\subsection{Method}

The vulnerability assessment of the existing RC building was checked using the Priority Index (PI) method. The PI method was studied by Hassan and Sozen using data from the Turkey earthquake (Nyein 2018). It was tested by O'Brien et al. in Haiti (Nyein 2018), following which it was 
found that a smaller priority index corresponds to higher seismic vulnerability. The PI method does not require timeconsuming and impractical dynamic analysis. Furthermore, this method is developed for low-rise buildings, masonry infill walls, non-engineered buildings, and poor reinforcement detailing (Hassan and Sozen 1997).

Hassan and Sozen (1997) have defined vulnerability indices related to base shear strength as follows (Equations 1, 2, and 3).

$$
\begin{gathered}
\text { Column Index }=\frac{1}{2} \frac{A_{\mathrm{col}}}{A_{\text {floor }}} \\
\text { Wall Index }=\frac{A_{\mathrm{RC} \text { wall }}+\frac{1}{10} A_{\mathrm{mw}}}{\sum A_{\text {floor }}} \\
\text { Priority Index }=\frac{0.5 A_{\mathrm{col}}+\sum A_{\mathrm{RC} \text { wall }}+\frac{1}{10} \sum A_{\mathrm{mw}}}{A_{\text {floor }}}
\end{gathered}
$$

where $A_{\text {col }}$ is the cross-sectional area of columns at ground level, $A_{\mathrm{RC} \text { wall }}$ is the cross-sectional area of $\mathrm{RC}$ walls in one horizontal direction, $A_{\mathrm{mw}}$ is the cross-sectional area of infill masonry walls in one horizontal direction, and $A_{\text {floor }}$ is the summation of floor areas above the base level.

This method requires only the dimensions of the structure as the input and is based on defining the position of a building on a two-dimensional plot using the wall and column indices. The wall index, WI, is the ratio of the effective wall area at the base of the building to the total floor area above the base. In the computation of the effective area, $100 \%$ of reinforced concrete walls, $10 \%$ of non-reinforced infill walls, and $50 \%$ of column area are considered effective. Hassan and Sozen (1997) observed the vulnerability of reinforced concrete structure to decrease with increasing combinations of column and wall indexes. It follows that vulnerability decreases as the sum of column and wall indices increase. An additional index was defined by Hassan and Sozen (1997) as the sum of the column and wall indices. It was termed the "Priority Index." According to Turkey earthquake damage data, a building is vulnerable to earthquakes if its PI value is less than 0.4, and non-vulnerable to earthquakes if its PI value is greater than or equal to 0.4 (Dönmez and Pujol 2005). Furthermore, the PI value can be classified into five categories. When PI values range from 0 to 0.099 , the building is defined as collapsible, $0.1-0.199$ as severe, $0.2-0.299$ as in a moderate state, 0.3-0.399 as light, and $\geq 0.4$ as non-vulnerable (Zhou et al. 2013).

\subsection{Tools and materials}

An investigation was conducted on whether the actual strength, arrangement, and sizes of reinforcing bars and concretes constructed are complying with a design drawing. The investigation materials used were a concrete rebound hammer, rebar detectors, Vernier calliper, and measuring tape. Non-linear static pushover analysis was carried out in SAP2000 software to investigate the perfor- mance of the building before and after retrofitting based on the three earthquake hazard levels.

\subsection{Evaluation of the existing building}

In this study, the vulnerability and performance of existing school RC building in seismic zone 4 of Mandalay was evaluated. The school was a three-story RC building, which was designed only for gravity load and constructed nearly 20 years ago, so it was necessary to evaluate the structural performance with the additional seismic load. The elevation and plan view of the building is shown in Figure 1.

\subsubsection{Assessment of seismic vulnerability}

The vulnerability assessment of the existing RC building was checked using the Priority Index (PI) method. The PI method was used to determine the vulnerable conditions of the existing building. The required data for this method were the building plan dimensions, column and wall crosssections, and number of stories. Priority indices were calculated using Equations 1, 2, and 3. The existing building had two column sizes of $12 \times 12^{\prime \prime}$ and $15 \times 20^{\prime \prime}$ and the thickness of both interior and exterior masonry infill walls was 4.5". There was no RC wall. The ground floor plan of the existing building is shown in Figure 1.

After calculating the Priority Index (PI) value (Table 1), the existing building was found to be vulnerable, with PI values of $0.19 \%$ and $0.21 \%$ in the NS and EW directions, respectively, below the allowable limit of $0.4 \%$.

\subsubsection{Performance evaluation under pushover analysis}

Performance points and performance levels of these buildings were determined with the FEMA 356 and Capacity-

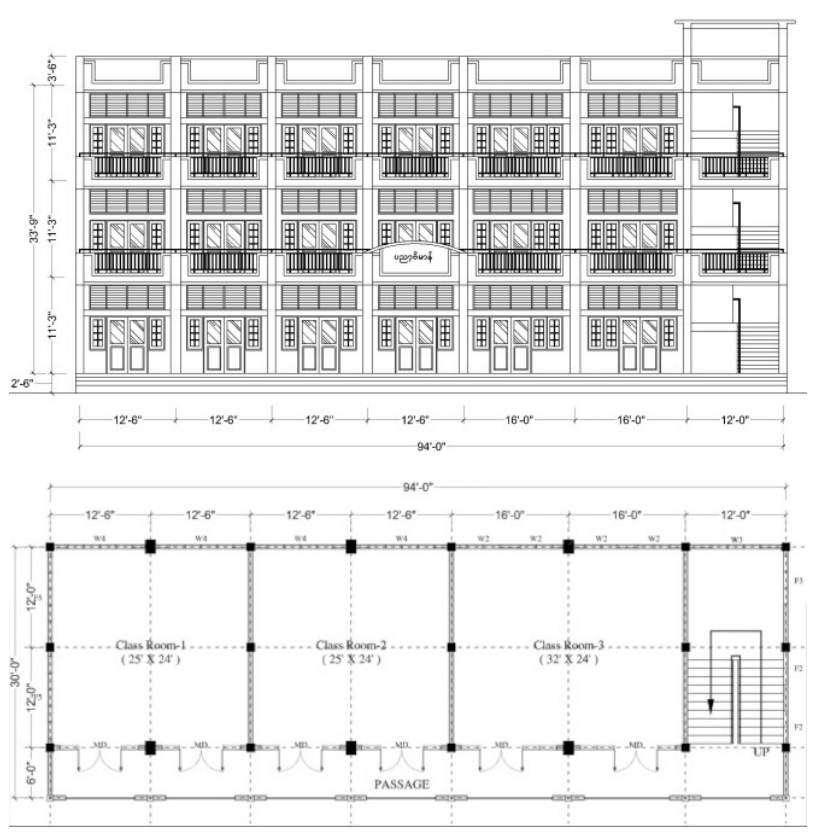

FIGURE 1. Elevation and plan view of the school building.

TABLE 1. Priority Index value for existing building in N-S and E-W directions.

\begin{tabular}{ccccccccc}
\hline \multirow{2}{*}{ No } & Floor area $\left(\mathrm{ft}^{2}\right)$ & Column area $\left(\mathrm{ft}^{2}\right)$ & M. wall area N-S $\left(\mathrm{ft}^{2}\right)$ & \multirow{2}{*}{ M. wall area E-W $\left(\mathrm{ft}^{2}\right)$} & \multicolumn{2}{c}{ PI value } & \multirow{2}{*}{ Allowable } & \multirow{2}{*}{ Remark } \\
\cline { 5 - 8 } & & & & & N-S & E-W & \\
\hline 1 & 8460 & 22.5 & 45 & 66 & $0.19 \%$ & $0.21 \%$ & $0.4 \%$ & 1 \\
\hline
\end{tabular}


TABLE 2. Checking performance levels for existing building.

\begin{tabular}{|c|c|c|c|c|c|c|}
\hline \multirow[t]{2}{*}{ Direction } & \multirow[t]{2}{*}{ Seismic ground motion } & \multirow[t]{2}{*}{ Base shear (kip) } & \multirow[t]{2}{*}{ Displacement (in) } & \multicolumn{2}{|c|}{ Performance level } & \multirow[t]{2}{*}{ Remark } \\
\hline & & & & Provided level & Allowable level & \\
\hline \multirow[t]{3}{*}{ Push X } & SE & 221.1 & 4.406 & C & 0,10 & Not OK \\
\hline & DBE & NA & NA & NA & LS & Not OK \\
\hline & MCE & NA & NA & NA & $\mathrm{CP}$ & Not OK \\
\hline \multirow[t]{3}{*}{ Push Y } & SE & NA & NA & NA & 0,10 & Not OK \\
\hline & DBE & NA & NA & NA & LS & Not OK \\
\hline & MCE & NA & NA & NA & $\mathrm{CP}$ & Not OK \\
\hline
\end{tabular}

Spectrum Method of ATC 40. In this study, the performance objectives were basic safety performance objectives: operational (O) level and immediate occupancy (IO) level under SE, life safety (LS) performance level under DBE, and collapse prevention (CP) level under MCE earthquake (Applied Technology Council 1996). Table 2 shows the performance levels for the existing building.

After nonlinear static pushover analysis, the performance of the existing building was found to fall in the collapse (C) damage level in Serviceability Earthquake (SE). The existing performance level was not satisfactorily within the allowable limit of Immediate Occupancy (IO) level in $\mathrm{SE}$, and therefore the existing building was deemed to be in need of retrofitting.

\subsection{Retrofit strategies}

A retrofit strategy is a technical option for improving the strength and other attributes of resistance of a building or a member to seismic forces. Retrofit strategies can be classified under global and local strategies. A global retrofit strategy targets the performance of the entire building under lateral loads. A local retrofit strategy targets the seismic resistance of a member, without significantly affecting the overall resistance of the building (Chakrabarti et al. 2008). The local strategy tends to be the most economical retrofitting approach when only a few of the building's components are inadequate (Federal Emergency Management Agency 2000). In this study, there was a $45 \%$ deficiency in beams and $22 \%$ deficiency in columns. Therefore, the global retrofit strategy was suitable for the building in cases of structural consideration, economical point of view, workability, and time consumption according to FEMA 356. In this study, a 10-inch thick reinforced concrete shear wall, 2-inch thick steel plate shear wall, and C15x50 steel bracing were selected as global retrofit strategies.

\section{RESULTS AND DISCUSSION}

\subsection{Retrofit with RC shear wall}

Shear walls are efficient, both in terms of construction cost and effectiveness in minimizing earthquake damage in structural and non-structural elements. Properly designed and detailed buildings with shear walls have been shown to have good performance in past earthquakes (Sahin 2014). It is an extremely effective method of increasing both building strength and stiffness. A shear wall system is often economical and tends to be readily compatible with most existing concrete structures (Applied Technology Council 1996). Figures $2 \mathrm{a}, 2 \mathrm{~b}$, and $2 \mathrm{c}$ show cases 1,2 , and 3 of the retrofit with the RC shear wall.

Tables 3 and 4 show the performance points and performance levels of cases 1,2 , and 3 for retrofitting with $\mathrm{RC}$ shear wall in an $\mathrm{X}$ and $\mathrm{Y}$ earthquake direction. In both earthquakes, the lowest displacements were found in case 1. However, the performance levels of case 1 in DBE and MCE were not satisfactorily within the allowable limits.

\subsubsection{Method statement for installation of RC shear wall}

Shear walls were connected to the model structure by dowels placed into the holes drilled in the faces of the beams
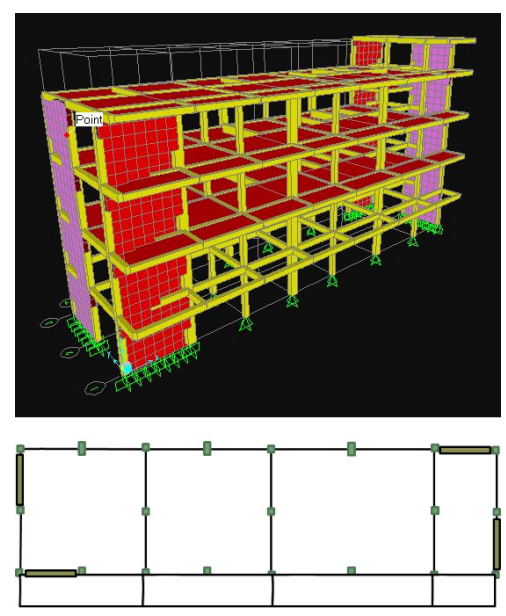

(a)
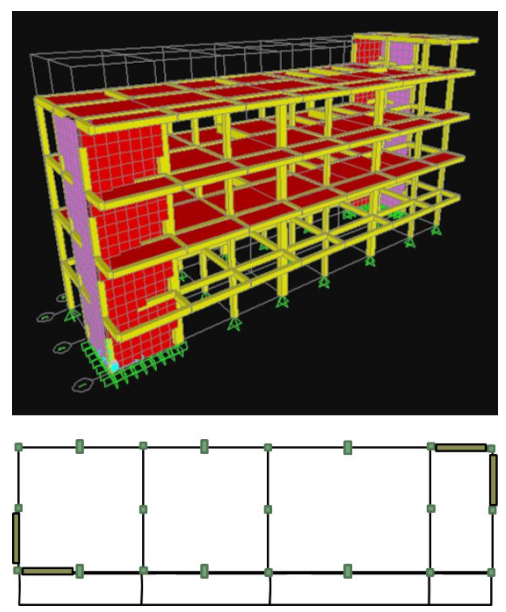

(b)
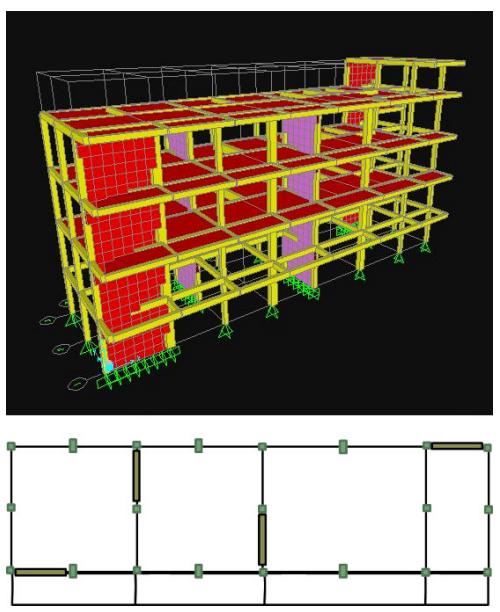

(c)

FIGURE 2. a) Case 1 of RC shear wall; b case 2 of RC shear wall; c) case 3 of RC shear wall. 
TABLE 3. Retrofit with RC shear wall (Push X).

\begin{tabular}{llccc}
\hline \multirow{2}{*}{ Case } & \multirow{2}{*}{ SGM $^{*}$} & \multicolumn{2}{c}{ Performance point } & \multirow{2}{*}{ Performance level } \\
\cline { 3 - 4 } & & Force (kip) & Displacement (in) & \\
\hline \multirow{2}{*}{2} & SE & 642.362 & 1.023 & 0 \\
& DBE & 974.758 & 1.650 & IO \\
& MCE & 1364.400 & 2.498 & $\mathrm{C}$ \\
& SE & 1075.770 & 1.619 & $\mathrm{IO}$ \\
& DBE & 1567.567 & 2.703 & $\mathrm{C}$ \\
& MCE & 2220.131 & 4.300 & $\mathrm{C}$ \\
& SE & 650.483 & 1.164 & $\mathrm{O}$ \\
& DBE & 991.661 & 1.932 & $\mathrm{IO}$ \\
& MCE & 1383.900 & 3.176 & $\mathrm{C}$ \\
\hline
\end{tabular}

*Seismic ground motion.

TABLE 4. Retrofit with RC shear wall (Push Y).

\begin{tabular}{llccc}
\hline \multirow{2}{*}{ Case } & \multirow{2}{*}{ SGM $^{*}$} & \multicolumn{2}{c}{ Performance point } & \multirow{2}{*}{ Performance level } \\
\cline { 3 - 4 } & & Force (kip) & Displacement (in) & \\
\hline \multirow{2}{*}{1} & SE & 632.005 & 1.131 & 0 \\
& DBE & 961.101 & 1.812 & $\mathrm{C}$ \\
& MCE & 1352.787 & 2.733 & $\mathrm{C}$ \\
& SE & 1057.986 & 1.426 & 0 \\
& DBE & 1571.406 & 2.276 & $\mathrm{C}$ \\
& MCE & 2271.848 & 3.507 & $\mathrm{C}$ \\
& SE & 464.058 & 1.426 & 0 \\
& DBE & 624.798 & 2.247 & 0 \\
& MCE & 842.917 & 3.474 & 10 \\
\hline
\end{tabular}

*Seismic ground motion.

and columns. Dowels were fixed into the old concrete by epoxy resin. Dowels were equidistantly installed onto the column and beam surfaces in contact with the exterior shear walls. Longitudinal reinforcements of the SWs were anchored to the same continuous footing as the columns (Kaplan et al. 2011).

\subsection{Retrofit with RC shear wall with openings}

Figures 3a, 3b, and 3a show cases 1, 2, and 3 of retrofitting with RC shear walls with openings. These were in the same locations and of the same thickness as the RC shear walls without openings.

Tables 5 and 6 show the performance points and performance levels of cases 1, 2, and 3 of retrofitting with RC shear walls with openings in $\mathrm{X}$ and $\mathrm{Y}$ earthquake directions.
TABLE 5. Retrofit with RC shear wall with opening (Push X).

\begin{tabular}{llccc}
\hline \multirow{2}{*}{ Case } & \multirow{2}{*}{ SGM $^{*}$} & \multicolumn{2}{c}{ Performance point } & \multirow{2}{*}{ Performance level } \\
\cline { 3 - 4 } & & Force (kip) & Displacement (in) & \\
\hline \multirow{2}{*}{1} & SE & 601.784 & 1.209 & 0 \\
& DBE & 901.639 & 1.972 & 10 \\
& MCE & 1263.556 & 3.050 & $\mathrm{C}$ \\
& SE & 908.070 & 1.503 & $\mathrm{C}$ \\
& DBE & 1324.584 & 2.400 & $\mathrm{C}$ \\
& MCE & NA & NA & - \\
& SE & 684.981 & 1.491 & 0 \\
& DBE & 986.847 & 2.491 & IO \\
& MCE & NA & NA & - \\
\hline
\end{tabular}

*Seismic ground motion.

TABLE 6. Retrofit with RC shear wall with opening (Push Y).

\begin{tabular}{llccc}
\hline \multirow{2}{*}{ Case } & \multirow{2}{*}{ SGM $^{*}$} & \multicolumn{2}{c}{ Performance point } & \multirow{2}{*}{ Performance level } \\
\cline { 3 - 4 } & & Force (kip) & Displacement (in) & \\
\hline \multirow{2}{*}{1} & SE & 569.302 & 1.062 & 0 \\
& DBE & 822.834 & 1.697 & 0 \\
& MCE & 1150.619 & 2.689 & $\mathrm{C}$ \\
& SE & 887.640 & 1.850 & $\mathrm{C}$ \\
& DBE & 1282.289 & 3.087 & $\mathrm{C}$ \\
& MCE & $\mathrm{NA}$ & $\mathrm{NA}$ & - \\
& $\mathrm{SE}$ & 466.016 & 1.546 & 0 \\
& DBE & 625.775 & 2.434 & 0 \\
& MCE & 847.046 & 3.826 & $\mathrm{O}$ \\
\hline
\end{tabular}

*Seismic ground motion.

In both earthquake scenarios, the lowest displacements are found in case 1 . But the performance levels of case 1 in MCE were not satisfactory within the allowable limits.

\subsection{Retrofit with steel plate shear wall}

Steel plate shear walls allow for less structural wall thickness that concrete shear walls and result in a lesser building weight compared with buildings that use concrete shear walls, which results in a reduction of foundation loads due to gravity and overall building seismic loads (Sahin 2014). The use of a steel plate shear wall system also reduces construction time (Sahin 2014). The locations of the steel plate shear walls were the same as that of the RC shear walls. Figures $4 \mathrm{a}, 4 \mathrm{~b}$, and $4 \mathrm{c}$ show cases 1,2 and 3 of retrofitting with steel plate shear walls.

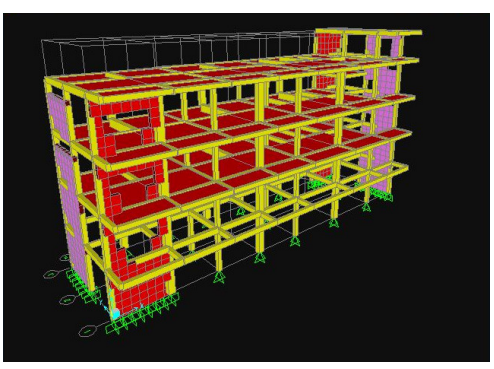

(a)

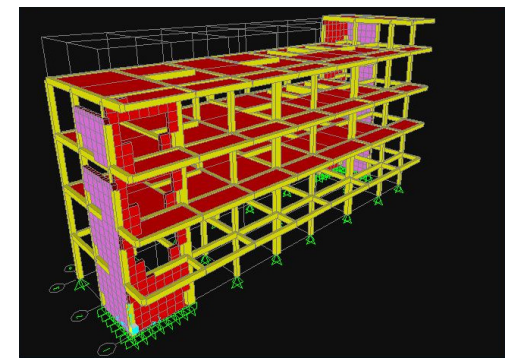

(b)

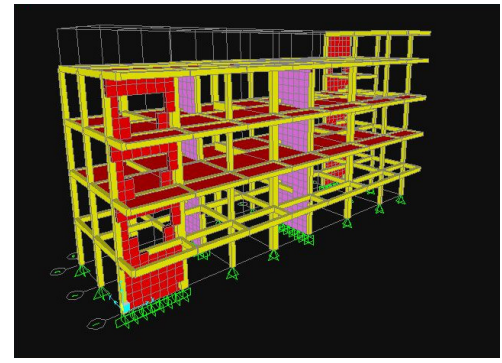

(c)

FIGURE 3. a) Case 1 of RC shear wall with opening; b case 2 of RC shear wall with opening; c) case 3 of RC shear wall with opening. 
TABLE 7. Retrofit with steel plate shear wall (Push X).

\begin{tabular}{llccc}
\hline \multirow{2}{*}{ Case } & \multirow{2}{*}{ SGM* } & \multicolumn{2}{c}{ Performance point } & \multirow{2}{*}{ Performance level } \\
\cline { 3 - 4 } & & Force (kip) & Displacement (in) & \\
\hline \multirow{2}{*}{2} & SE & 556.478 & 0.792 & 0 \\
& DBE & 901.514 & 1.264 & 0 \\
& MCE & 1235.334 & 2.143 & 10 \\
& SE & 966.694 & 1.269 & 10 \\
& DBE & 1360.755 & 2.336 & D \\
& MCE & 1759.540 & 3.985 & D \\
& SE & 641.894 & 0.950 & 0 \\
& DBE & 941.497 & 1.686 & IO \\
& MCE & 1258.009 & 2.935 & $\mathrm{C}$ \\
\hline
\end{tabular}

*Seismic ground motion.

Tables 7 and 8 show the performance points and performance levels of cases 1, 2, and 3 in terms of retrofitting with steel plate shear walls in $\mathrm{X}$ and $\mathrm{Y}$ directions of an earthquake. In both earthquake scenarios, the lowest displacements were found in case 1 . The performance levels of all cases in three earthquake hazard levels were satisfactorily within the allowable limits.

\subsubsection{Method statement for installation of steel plate shear walls}

Firstly, the holes are drilled in existing columns and cleaned with a compressed air gun or blow out pump. After moistening these holes with a pump, the injectable adhesive anchors are filled into these holes. Spring washers are placed to prevent fastening or loosening due to vibrations (i.e. seismic loads). Then, steel plates are carried to the place and
TABLE 8. Retrofit with steel plate shear wall (Push Y).

\begin{tabular}{llccc}
\hline \multirow{2}{*}{ Case } & SGM* & \multicolumn{2}{c}{ Performance point } & \multirow{2}{*}{ Performance level } \\
\cline { 3 - 4 } & & Force (kip) & Displacement (in) & \\
\hline \multirow{2}{*}{1} & SE & 598.884 & 0.786 & 0 \\
& DBE & 956.007 & 1.257 & 0 \\
& MCE & 1358.789 & 1.890 & 0 \\
& SE & 991.320 & 0.963 & 0 \\
& DBE & 1532.057 & 1.569 & 10 \\
& MCE & 2189.141 & 2.434 & 10 \\
& SE & 467.972 & 1.313 & 0 \\
& DBE & 658.000 & 2.164 & 10 \\
& MCE & 894.671 & 3.423 & 10 \\
\hline
\end{tabular}

*Seismic ground motion.

installed onto the columns and beams using high-tension bolts (Fathalizadeh 2017).

\subsection{Retrofit with steel bracing}

Braced steel frames are another common method of enhancing an existing building's stiffness and strength (Applied Technology Council 1996). Typically, braced frames provide lower levels of stiffness and strength than shear walls, but they add far less mass to the structure compared with shear walls, can be constructed with less loss of light, and have a smaller effect on traffic patterns within the building (Applied Technology Council 1996). In this study, a V-inverted steel bracing was selected to retrofit the existing structure. Figures $5 \mathrm{a}, 5 \mathrm{~b}, 5 \mathrm{c}$, and $5 \mathrm{~d}$ show cases 1,2 , 3 , and 4 of retrofitting with steel bracing.

Tables 9 and 10 show the performance points and performance levels of cases 1, 2, 3, and 4 for retrofitting with

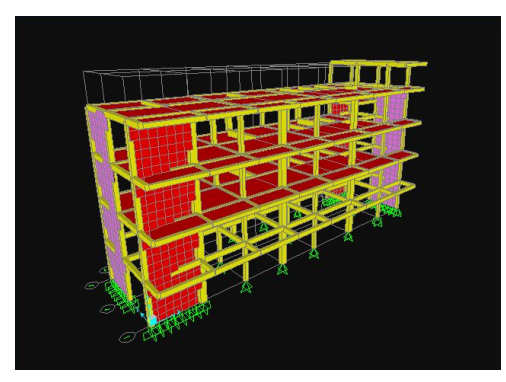

(a)

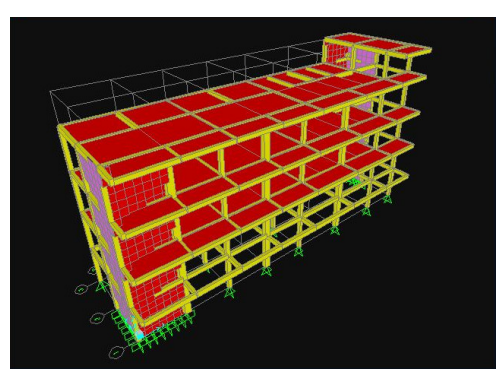

(b)

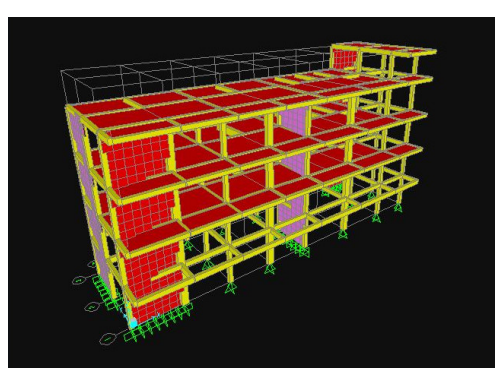

(c)

FIGURE 4. a) Case 1 of steel plate shear wall; b case 2 of steel plate shear wall; c) case 3 of steel plate shear wall.
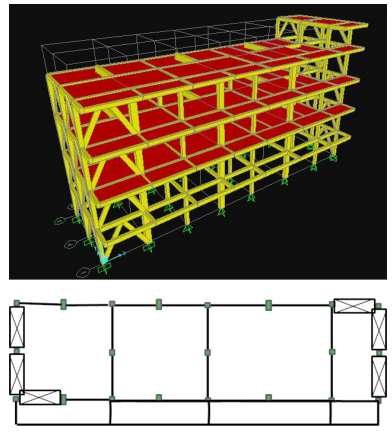

(a)
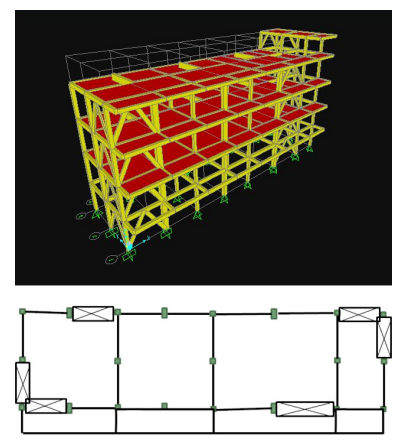

(b)
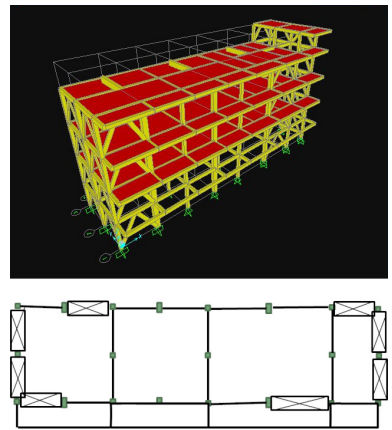

(c)
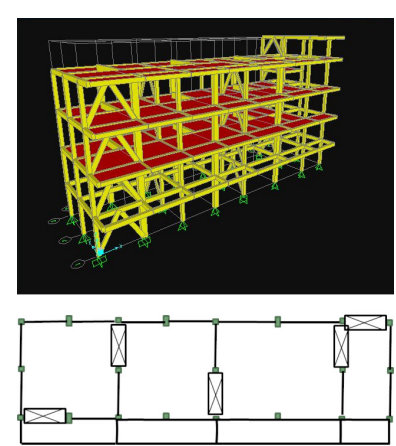

(d)

FIGURE 5. a) Case 1 of steel bracing; b) case 2 of steel bracing; c) case 3 of steel bracing; d) case 4 of steel bracing. 
TABLE 9. Retrofit with steel bracing (Push X).

\begin{tabular}{llccc}
\hline \multirow{2}{*}{ Case } & \multirow{2}{*}{ SGM $^{*}$} & \multicolumn{2}{c}{ Performance point } & \multirow{2}{*}{ Performance level } \\
\cline { 3 - 4 } 1 & & Force (kip) & Displacement (in) & \\
\hline \multirow{2}{*}{2} & SE & 432.295 & 1.777 & E \\
& DBE & NA & NA & - \\
& MCE & NA & NA & - \\
& SE & 587.989 & 1.085 & 0 \\
& DBE & NA & NA & - \\
3 & MCE & NA & NA & - \\
& SE & 576.854 & 0.998 & 0 \\
& DBE & NA & NA & - \\
& MCE & NA & NA & - \\
4 & SE & 338.738 & 1.183 & - \\
& DBE & NA & NA & - \\
& MCE & NA & NA & \\
& & &
\end{tabular}

*Seismic ground motion.

TABLE 10. Retrofit with steel bracing (Push Y).

\begin{tabular}{|c|c|c|c|c|}
\hline \multirow[t]{2}{*}{ Case } & \multirow[t]{2}{*}{ SGM* } & \multicolumn{2}{|c|}{ Performance point } & \multirow[t]{2}{*}{ Performance level } \\
\hline & & Force (kip) & Displacement (in) & \\
\hline \multirow[t]{3}{*}{1} & SE & 544.155 & 1.150 & C \\
\hline & DBE & NA & NA & - \\
\hline & MCE & NA & NA & - \\
\hline \multirow[t]{3}{*}{2} & SE & 340.243 & 2.072 & C \\
\hline & DBE & NA & NA & - \\
\hline & MCE & NA & NA & - \\
\hline \multirow[t]{3}{*}{3} & SE & 526.485 & 0.951 & C \\
\hline & DBE & 669.672 & 1.731 & $\mathrm{C}$ \\
\hline & MCE & NA & NA & - \\
\hline \multirow[t]{3}{*}{4} & SE & 360.506 & 0.850 & C \\
\hline & DBE & NA & NA & - \\
\hline & MCE & NA & NA & - \\
\hline
\end{tabular}

*Seismic ground motion.

steel bracing in $\mathrm{X}$ and $\mathrm{Y}$ earthquake directions. Retrofitting with steel bracing required more space compared with shear walls. In addition, the performance levels of all cases with steel bracing were not satisfactorily within the allowable limits.

\section{CONCLUSIONS}

An existing building in Mandalay, Myanmar, was retrofitted using RC shear walls (with and without openings), steel plate shear walls, and steel bracing. Retrofitting with steel bracing needed more space than that with RC shear walls and steel plate shear walls. Meanwhile, steel plate shear walls had the lowest displacement and the best performance compared with the other techniques. Therefore, retrofitting with steel plate shear walls was selected as a suitable retrofitting strategy for this case study.

\section{ACKNOWLEDGMENTS}

The authors would like to express their heartfelt gratitude to Dr. Nilar Aye, Professor and Head of the Department of Civil Engineering, as well as to all of the teachers at the Department of Civil Engineering, Mandalay Technological University, for their encouragement and suggestions.

\section{AUTHORS' CONTRIBUTIONS}

TT designed the study and analyzed the data. NSLMT supervised the study. NMH co-supervised the study. TT wrote the manuscript. All authors read and approved the final version of the manuscript.

\section{COMPETING INTERESTS}

The authors have no competing interests to declare.

\section{REFERENCES}

Applied Technology Council. 1996. Seismic evaluation and retrofit of concrete buildings. Redwood City: Applied Technology Council.

Chakrabarti A, Menon D, Sengupta AK. 2008. Handbook on seismic retrofit of buildings. Oxford: Alpha Science International.

Dönmez C, Pujol S. 2005. Spatial distribution of damage caused by the 1999 earthquakes in Turkey. Earthq Spectra. 21(1):53-69. doi:10.1193/1.1850527.

Fathalizadeh A. 2017. Introducing two most common types of shear walls and their construction methods. J Civ Eng Res. 1(1):8-12. http://www.journals-researchers.c om/ojs/index.php/jcer/article/view/1.

Federal Emergency Management Agency. 2000. Prestandard and commentary for the seismic rehabilitation of buildings. Washington, D.C.: Federal Emergency Management Agency.

Hassan AF, Sozen MA. 1997. Seismic vulnerability assessment of low-rise buildings in regions with infrequent earthquakes. ACI Struct J. 94(1):31-39. doi:10.14359/4 58.

Kaplan H, Yilmaz S, Cetinkaya N, Atimtay E. 2011. Seismic strengthening of RC structures with exterior shear walls. Sadhana. 36(1):17-34. doi:10.1007/s12046-011-0 002-z.

Nyein EK. 2018. Development of seismic vulnerability-map for RC buildings in Patheingyi Township and Mandalay.

Sahin C. 2014. Seismic retrofitting of existing structures. Portland: Portland State University.

Thant M, Ngal NL, Tun ST, Thein M, Swe W, Myint T. 2012. Seismic hazard assessment for Myanmar. Yangon: Myanmar Earthquake Committee, Myanmar Geoscience Society.

Thwe T, Thwin NSLM. 2020. Improvement of seismic performance for existing RC building with shear walls. Proceedings of the Universal Academic Cluster International February Conference; Bangkok, Thailand. p. 3448.

Zhou W, Zheng W, Pujol S. 2013. Seismic vulnerability of reinforced concrete structures affected by the 2008 Wenchuan earthquake. Bull Earthq Eng. 11(6):20792104. doi:10.1007/s10518-013-9517-5. 